\title{
УДК 340.143
}

https://doi.org/10.52058/2786-5274-2022-2(4)-122-133

Стець Олег Миколайович доктор юридичних наук, доцент, завідувач кафедри конституційного, міжнародного та приватного права, Криворізький факультет Національного університету «Одеська юридична академія», проспект Миру, 22, м. Кривий Ріг, 50000, https://orcid.org/ 0000-0003-4211-2687

Варенья Наталія Михайлівна кандидат юридичних наук, провідний науковий співробітник, Національна академія Служби безпеки України, вул. Михайла Максимовича, 22, м. Київ, 03022, https://orcid.org/0000-0002-2797-197X

Рижов Ігор Миколайович доктор юридичних наук, професор, головний науковий співробітник, Національна академія Служби безпеки України, вул. Михайла Максимовича, 22, м. Київ, 03022, https://orcid.org/0000-0001-8009-5895

\section{ПРАВОВА ДОКРИНА КОНСТИТУЦІОНАЛІЗМУ}

Анотація. У статті досліджується правова доктрина конституціоналізму через призму безпеки та розвитку соціуму, як одного із важливих системних елементів захисту національної державності в сучасних умовах. Проаналізовано теоретичну сутність понять «безпека» та «соціальна система» визначено їх основні ознаки. Встановлено, що метою конституційної безпеки являється забезпечення оптимального алгоритму функціонування соціальної системи. Визначено, що безпекова компетентність $є$ невід'ємною і потребує репрезентованості не на периферії чи в підтекстах, а в переліку ключових компетентностей у базових документах, що регулюють сферу освіти як на міжнародному, так i національному рівнях. Встановлено актуальність превентивних заходів стосовно запобігання подальшому розвитку чинників, що негативно впливають на сферу безпеки в суспільстві. Визначено, що найважливішою особливістю існування будь-якого суспільства $\epsilon$ тісний взаємозв'язок між його розвитком і безпекою. Встановлено, що завдання безпеки виходять за межі необхідності захисту певного стану соціальної системи або iï складових і полягають у формуванні умов, що забезпечують іiі розвиток, а відповідно, сталість і цілісність. Визначено, що основними вимогами до формування ефективної системи державного регулювання у сфері соціальної безпеки та захисту національної державності $€$ : застосування комплексного планування соціального розвитку; прогнозування показників безпечного розвитку соціальної сфери; реалізація загальнодержавних та цільових комплексних соціальних програм. Доведено, що в Україні набув актуальності інформаційний тероризм, що охоплює кібертероризм та медіа- 
тероризм, де для захисту національної державності необхідні такі елементи: законодавче унормування цієї сфери; підготовка фахівців у сфері протидії медіа-тероризму; удосконалення ризик-менеджменту антитерористичної безпеки в умовах розвитку віртуальних медіа, що повинно бути враховане в доктрині конституціоналізму.

Ключові слова: захист національної державності, національна безпека, конституціоналізм, соціальна система.

Stets Oleg Mykolayovych Doctor in Law, Associate Professor, Head of the Department of Constitutional, International and Private Law, Kryvyi Rih Faculty National University «Odesa Law Academy», Myru Ave, 22, Kryvyi Rih, 50000, https://orcid.org/ 0000-0003-4211-2687

Varenia Nataliia Mykhaylivna PhD in Law, Leading Researcher, National Academy of Security Service of Ukraine, Mikhail Maksimovich St., 22, Kyiv, 03022, https://orcid.org/0000-0002-2797-197X

Ryzhov Igor Mykolayovych Doctor of Law, Professor, Chief Researcher, National Academy of Security Service of Ukraine, Mikhail Maksimovich St., 22, Kyiv, 03022, https://orcid.org/0000-0001-8009-5895

\section{LEGAL DOCTRINE OF CONSTITUTIONALISM}

Abstract. The paper studies the legal doctrine of constitutionalism through the prism of security and development of society as one of the important systemic elements of protection of national statehood in modern conditions. The theoretical essence of the concepts of "security" and "social system" is analyzed and their main features are determined. It is established that the purpose of constitutional security is to ensure the optimal algorithm for the functioning of the social system. It is determined that security competence is inalienable and definitely needs to be represented not on the periphery or in the subtexts, but in the list of key competencies in the basic documents governing the field of education at both international and national levels. The urgency of preventive measures to prevent further development of factors that negatively affect the security of society. It is determined that the most important feature of the existence of any society is the close relationship between its development and security. It is established that security tasks go beyond the need to protect a certain state of the social system or its components and are to create conditions that ensure its development, and, accordingly, sustainability and integrity. It is determined that the main requirements for the formation of an effective system of state regulation in the field of social security and protection of national statehood are: the use of integrated planning of social development; forecasting indicators of safe development of the social sphere; implementation of national and targeted 
comprehensive social programs. It is determined that information terrorism, which includes cyberterrorism and media terrorism, has become relevant in Ukraine, where the elements for the protection of national statehood could be: legislative regulation of this area; training of specialists in the field of counteraction to media terrorism; improving the risk management of anti-terrorist security in the development of virtual media, which should be taken into account in the doctrine of constitutionalism.

Keywords: protection of national statehood, national security, constitutionalism, social system.

Постановка проблеми. Серед актуальних завдань, що стоять на сьогодні перед країною і суспільством, пріоритетним напрямком є захист національної державності. Проблема підвищення ролі держави у забезпеченні безпеки $\epsilon$ надзвичайно актуальною у зв'язку з тим, що система соціально-економічної безпеки в Україні формується лише фрагментарно без достатнього теоретикометодологічного обгрунтування. Внаслідок цього в економіці та соціальній сфері накопичуються негативні явища та тенденції, які виявляються у деформаціях соціальної структури, економічній десоціалізації, соціальнокультурній деградації та слабкому соціальному захисті особистості.

Сучасне суспільство характеризується наявністю особливих технологій провокації соцієтальних і соціальних конфліктів, метою яких $\epsilon$ примусова корекція або зміна конституційних норм. Питому вагу вражаючого фактора таких загроз складають нематеріальні активи (соціально-політичні, технологічні, інформаційні, фінансові тощо), які $є$ наслідком неефективного використання безпекової складової інформаційно-інтелектуального капіталу держави (соціальної системи).

За таких умов конституціоналізм, як політична система, що спирається на конституцію і конституційні методи управління, має розглядатися як суб'єкт забезпечення національної безпеки, який потребує побудови системи захисту. Саме тому набуває глобального значення проблема забезпечення цілісності цивілізаційних процесів, окреслених конституційними нормами через унеможливлення спроб примусової зміни або корекції алгоритму соціального управління задля впливу на сталий порядок речей, безпеку особистості, права i свободи, громадську безпеку та іiі основні об'єкти - матеріальні і духовні цінності суспільства й державну безпеку - конституційний лад, суверенітет i територіальну цілісність тощо.

У зв’язку з цим захист національної державності як ключового чинника соціально-економічного розвитку держави об'єктивно потребує комплексного вивчення на засадах системного підходу, а не лише на рівні людини, суб'єкта господарювання, виду економічної діяльності чи суспільства, а й у функціональних сферах зайнятості населення, ринку праці, міграційної безпеки. Тому структурна згуртованість підрозділів формування та розвитку системи соціально-економічної безпеки є необхідною вимогою економічного зростання, 
дестабілізація якої може призвести до суттєвих негативних соціальноекономічних наслідків. 3 огляду на викладене, розробка механізмів і засобів державної політики регулювання соціально-економічної безпеки в системі стратегічних і тактичних пріоритетів захисту національної державності України є досить актуальною для розгляду правової доктрини конституціоналізму.

Аналіз останніх досліджень і публікацій. Тематику правової доктрини конституціоналізму досліджує значна кількість науковців. Зокрема, наукові праці А. А. Мироєдова, А. М. Федорової, Г. В. Гутмана, Г. П. Ситника, I. Лексіна, М. К. Шапочки, О. В. Ілляшенка, О. І. Карінцева, О. Ілляша, О. О. Шкарупета, С. В. Федіна, С. М. Шевченка, присвячені аналізу нормативно-правовому регулюванню питань забезпечення національної безпеки та безпечного середовища життя громадян.

Постановка завдання. Метою роботи $є$ дослідження правової доктрини конституціоналізму через призму безпеки та розвитку соціуму, державного управління соціальними системами для виявлення передумов та коригування кризових станів соціального характеру. Для досягнення мети визначено такі завдання:

1) в загальних рисах проаналізувати безпеку України;

2) визначити сутність понять безпеки та соціальної системи;

3) проаналізувати категорії та об'єкт безпеки;

4) визначити вимогами до формування ефективної системи державного регулювання у сфері соціальної безпеки та захисту національної державності;

5) проаналізувати кібертероризм та медіа-тероризм в Україні.

При проведенні дослідження були використані загальнонаукові й спеціальні методи дослідження, зокрема аналіз і синтез, порівняння, узагальнення, системно-структурний аналіз.

Виклад основного матеріалу. Сучасні виклики національній безпеці України здобули такого ступеня, за якого без створення та реалізації послідовної системної державної політики для захисту національних потреб населення та відповідних механізмів іiі реалізації, які на порядку денному можуть поставити запит щодо екзистенції України як цілісної та суверенної держави [1, с. 13].

Станом на 24.10.2020 p. набула чинності нова редакція Закону «Про національну безпеку України» [2], який у відповідності до статей 1, 2, 17, 18 i 92 Конституції України [3] визначає положення та принципи національної безпеки, цілі та головні основи державної політики, які забезпечуватимуть населенню та кожному громадянину захист національної державності від імовірних загроз. Конституція України встановлює, що людина, іiі життя i здоров'я, честь і гідність, недоторканність і безпека визнаються в Україні найвищою соціальною цінністю, тому утвердження та асекурація прав і свобод людини є визначальним обов’язком країни. 
Громадська безпека у Законі «Про національну безпеку України» окреслюється таким чином: «захищеність життєво важливих для населення та особистості інтересів, прав і свобод людини і громадянина, асекурація яких являється першим завданням діяльності сил безпеки та інших державних органів їх посадових осіб та громадськості, які реалізують узгоджені дії стосовно імплементації і протекції національних інтересів від інспірації небезпек» [2].

Статтею 1 Закону «Про національну безпеку України» передбачено, що окрім іншого, введення нового документу - Стратегії громадської безпеки та цивільного захисту України, який сконцентрований на довготермінове планування і формується на базі Стратегії національної безпеки України за результатами дослідження громадської безпеки та цивільного захисту і виявляє вектори державної політики стосовно забезпечення захищеності життєво важливих для держави, населення та особистості інтересів, цілі та очікувані результати їх досягнення з урахуванням актуальних загроз [2, ст. 1].

Загальновідомо, що безпека являється такими кондиціями, в яких знаходиться інтегрована система, коли ефект зовнішніх чинників та внутрішніх факторів не підштовхує до перебігу справ, що вбачаються негативними по співвідношенню до даної інтегрованої системи у конгруенції до наявних, на даному етапі вимог, знань та розумінь.

Вирізняють наступні категорії безпеки:

1) безпека людини є такою кондицією особистості, коли вплив зовнішніх та внутрішніх чинників не спричиняє летальні наслідки, погіршення діяльності та розвитку організму, психіки, свідомості та особистості в цілому і не гальмує процес здобуття відповідних бажаних для особистості цілей;

2) національна безпека $\epsilon$ протекцією життєво значущих інтересів особистості та громадянина, населення та країни, за якої гарантується сталий розвиток суспільства, вчасне виявлення, запобігання і нейтралізація актуальних та потенційних загроз національним інтересам [4, с. 168].

У цьому контексті об'єкт безпеки трактується, як визначений порядок перебігу подій, своєрідна «чистота» шляху еволюційного розвитку людини та суспільства, ii захист від беззаконня у створенні та імплементації алгоритму соціального управління. Отже, визначальною метою конституційної безпеки являється асекурація оптимального алгоритму функціонування соціальної системи, а саме імплементацію передбачених конституцією норм та принципів організації та діяльності держави, що гарантують асекурацію цілісності країни, безпеки особистості, суспільства та держави шляхом усунення причин до видозміни основ конституційного ладу і порушення цілісності держави, чи суспільства та здатність держави припинити будь-які наміри проти них.

Найвищою соціальною цінністю в Україні визнаються безпека людини, іiі життя і здоров'я. У статті 27 Конституції України зазначено, що «кожна особистість має право захищати особисте життя і здоров'я, життя і здоров'я 
інших людей від протиправних посягань», проте насправді ця лінія не імплементується сповна, через те, що на різних етапах становлення особистості державою не передбачено спеціальні, відповідні віковим параметрам учнів/студентів заходів щодо навчання всіх специфічних особливостей імплементації ідей особистісної безпеки та безпеки держави в сучасних та прогностичних соціополітичних контекстах, які базуються на цінностях активного громадянства й активним створенням не лише знань, проте й відповідних навичок. Визначено, що коригування потребує навіть більше праксеологічна складова. Оскільки однією 3 головних цілей оновленого Стандарту освіти являється «формування компетентностей, котрі потрібні для соціалізації та громадянської активності, свідомого вибору подальшого життєвого шляху та самореалізації». У реалізації цього вектору, вважаємо, що безпекова компетентність являється невіддільною і від того неодмінно вимагає репрезентованості не на периферії чи в підтекстах, а в переліку ключових компетентностей у базових документах, які регулюють сферу освіти як на міжнародному, так і національному рівнях [3].

Потужна національна безпека як основний імператив розвитку сучасного суспільства об'єктивно вимагає від держави особливого підходу до забезпечення безпеки, захисту національної державності та вирішення проблем у сфері безпеки. Генеза безпеки в теорії соціального розвитку підтверджує провідну роль держави у забезпеченні безпеки в усіх іiі сферах: політичній, військовій, енергетичній, соціальній та економічній [5, с. 25].

3-за досить невтішних стосовно безпекових перспектив контекстах сучасності зростає актуальність превентивних заходів для запобігання подальшому розвитку факторів, які негативно позначаються на сфері безпеки в суспільстві. Під яким визначається не лише явище про інституційне регулювання, але й про спектр заходів із виховання та навчання населення щодо збереженості цінностей миру й толерантності в соціумі на всіх рівнях (особистісному, сімейному, у навчальних та професійних колективах, у дійсному й віртуальному просторах).

Соціальна система визначається як система, серед складових компонентів якої є людина. В уявленні людини мета соціальної системи розуміється не так однозначно, як це здійснюється в теорії систем. Людина як частина соціуму найчастіше під метою розуміє свідоме або підсвідоме прагнення до розв'язання проблеми, а не результат розв'язання проблеми. На перший погляд це визначається, як невагома відмінність у розумінні, однак за більш деталізованого розгляду вона ставить під сумнів незамінність властивості цільового призначення соціальної системи. Окремі галузі системології мають свої напрями розуміння та застосування поняття мети в системноорганізаційній діяльності [6].

Найважливішою характерною ознакою існування будь-якого суспільства являється щільний взаємозв’язок між його розвитком і безпекою. У «Великій 
радянській енциклопедії» щільний зв'язок між розвитком соціуму та безпекою розкривається розумінням безпеки як «стану, тенденцій розвитку та умов життєдіяльності соціуму, його структур, інститутів i установ, при яких асекурується збереження їх внутрішньої визначеності 3 об'єктивно зумовленими інноваціями та вільне функціонування, що відповідає власній природі і нею визначається» [7].

Тобто завдання безпеки виходять далеко за межі необхідності захисту певного стану соціальної системи або її складових і полягають у формуванні умов, що забезпечують її розвиток, а відповідно, сталість і цілісність:

- сталість, без якої неможливе збереження цілісності;

- цілісність, без якої неможливі зміни (розвиток);

- розвиток, без якого жива система втрачає сенс, не може функціонувати, тобто існувати.

Захищеність розвитку об’єктів соціальної системи передбачає запобігання, попередження та нейтралізацію небезпечних станів, які формують загрозу для розвитку та існування даних об’єктів або окремих його частин.

Соціальні системи є досить динамічними, тобто вони постійно змінюються й ці зміни $є$ умовою виникнення ситуації ризику. Відповідно сам факт існування суспільства вже становить загрозу для нього й це характерно для будь-яких соціальних систем: організації, сім’ї, творчого колективу, бізнесструктури, релігійної конфесії, політичної партії тощо. Проблема безпеки соціальної системи довгий час зводилася до забезпечення фізичної безпеки. Сьогодні в структурі безпеки основна, визначальна, системоутворююча роль належить соціальній безпеці, яка захищає життєво важливі інтереси людей і їх спільнот, держав від загроз у різних сферах життєдіяльності [6].

Основними вимогами до формування ефективної системи державного регулювання у сфері соціальної безпеки та захисту національної державності є: застосування комплексного планування соціального розвитку; прогнозування показників безпечного розвитку соціальної сфери; реалізація загальнодержавних та цільових комплексних соціальних програм. Доведено, що наукове обгрунтування державного регулювання сприяє визначенню фундаментальних положень системного підходу до вибору механізму, засобів і методів державного регулювання соціальної безпеки, що суттєво підвищить рівень та якість державного регулювання у сфері національного регулювання безпеки та захисту національної державності.

Нова парадигма побудови системи соціальної безпеки визначає їі як тріаду:

1) цілісна суспільна система взаємопов'язаних елементів;

2) організаційно тісна підсистема соціального забезпечення, яка характеризується сукупними взаємодіями iі компонентів (окремих видів безпеки);

3) стан та характеристики заходу досягнення оптимального рівня функціональної безпеки, реконструкції та розвитку соціальної системи. 
Для підтримки системи в умовах нестабільного середовища та внутрішніх перетворень (випадкових чи навмисних) необхідна спеціальна організація системи, яка забезпечить iї стійкість до загроз [8; 9; 10]. В умовах прискорення соціально-економічних змін та підвищення соціальної напруги ризики, що з'явилися в соціальній сфері, посилилися. Типологія ризиків у сфері соціальноекономічної безпеки дозволяє виявити зміни ентропії системи, можливості застосування кількісних підходів в управлінні нею та сформулювати ризик як усвідомлену можливість небезпеки щодо існування викликів і загроз системі.

Виокремлюють наступні підстави для існування переважних ризиків у сфері соціальної безпеки за такими періодами часу:

1) біхевіористський, що грунтується на визначенні основних типів індивідуального ставлення до ризиків та факторів, що визначають специфіку відносин усередині системи;

2) ситуаційний, що визначає стан узгодженості окремих методів і підходів управління ризиками та передбачає можливі позитивні та негативні наслідки їх впливу;

3) процесуальний, що визначає індивідуалізовані ризики, які широко проявляються в «суспільстві ризику»;

4) функціональний, що визначає напрямки впливу трансформації суспільства на ризики в соціально-економічній сфері;

5) системно-синергетичний (інтегральний), що грунтується на розрізненні функцій аналізу, оцінки та управління ризиками та підтверджує багатогранність та стійкість системи, яка здатна адаптуватися до мінливих умов середовища та усувати поточні загрози, а також наявність значної кількості небезпечних факторів, які одночасно впливають на систему національної безпеки у сфері відтворення населення, ринку праці та зайнятості, соціальній та міграційній сферах, що сприяють захисту національної державності [5].

Окрім того, з урахуванням політичної ситуації в Україні досить інтенсивно набув актуальності інформаційний тероризм, до складу якого входить кібертероризм та медіа-тероризм. Недостатня увага до цього напряму значно полегшує реалізацію кіберзагроз, а тому вимагає інформаційного, кадрового, наукового, організаційного, правового та психологічного забезпечення в контексті антитерористичної безпеки. Для захисту національної державності елементами кібертероризму та медіа-тероризму могли б стати: створення механізму протидії інформаційно-психологічній складовій гібридної війни; законодавче унормування даної сфери; підготовка спеціалістів, рекомендовано, з юридичною освітою у сфері протидії медіа-тероризму; удосконалення ризик-менеджменту антитерористичної безпеки через кондиції розвитку віртуальних медіа тощо (наприклад, дані заходи повинні бути враховані в доктрині конституціоналізму, як ідеї, які реально імплементувати у життя належним чином).

Сучасні загрози інформаційній безпеці можна виокремити через негативний, водночас в даний час не протизаконний, інформаційний вплив на 
свідомість та поведінку громадян, а також через здійснення впливу на інформаційні ресурси та інформаційно-технічну інфраструктуру. Ефективна протидія даним загрозам може бути досягнута тільки шляхом застосування комплексних підходів до визначення понять «інформаційна безпека», «інформаційний тероризм» в доктрині конституціоналізму, а протидія фейкам при цьому повинна стати складовим компонентом державної політики інформаційної безпеки для захисту національної державності.

У відповідності до Указу Президента України №685/2021 «Про рішення Ради національної безпеки і оборони України від 15 жовтня 2021 року «Про Стратегію інформаційної безпеки» під інформаційною безпекою України розуміється складова частина національної безпеки України, стан захищеності державного суверенітету, територіальної цілісності, демократичного конституційного ладу, та інших вагомих інтересів людини, суспільства i держави, за якого відповідним чином асекуруються конституційні права i свободи людини на збір, збереження, застосування та розповсюдження інформації, доступ до достовірної та об'єктивної інформації, існує ефективна система захисту і протидії нанесенню шкоди через розповсюдження негативних інформаційних впливів, у тому числі скоординоване розповсюдження недостовірної інформації, деструктивної пропаганди та інших інформаційних операцій, тощо [11].

Оскільки відсутність у чинному законодавстві всіх актуальних складових кібербезпеки не дає можливості створити та реалізувати цілісну систему протидії таким явищам.

Можна виокремити, що найближчим законодавчим трактуванням до термінів «інформаційний тероризм» та «медіа-тероризм» в українському законодавстві являється кібертероризм, який трактується як терористична діяльність, яка реалізується у кіберпросторі або з його застосуванням [12]. Однак воно не охоплює весь спектр імовірних протиправних дій терористичного характеру в інформаційній сфері. Адже сучасні терористичні організації можуть застосовувати для медіавпливу на владу та суспільство інформацію про:

- вже реалізовані терористичні акти або штучний виток інформації про начебто підготовку до даних видів актів;

- техногенні аварії та катастрофи, які з'явилися без втручання з боку терористів;

- кримінальні правопорушення, котрі не стосуються терористичних дій, водночас наслідки яких є відчутними для суспільства;

- події, змодельовані та візуалізовані засобами штучного інтелекту із застосуванням віртуальної та/або доповненої реальності;

- будь-які поєднання вказаних вище інформаційних посилів.

Отже, видається очевидною потреба розробки нових правових норм у сфері інформаційної безпеки, які б враховували сучасні дослідження у сфері перспективних напрямів розвитку інформаційних технологій та новітніх 
алгоритмів формування медіа-контенту. Необхідним також являється чітке встановлення кола суб'єктів, які повинні асекурувати інформаційну безпеку та протидіяти загрозам національним інтересам України в інформаційній сфері.

На нашу думку, ці завдання варто визначити для: Служби безпеки України, Міністерства культури i інформаційної політики України, Міністерства закордонних справ України, Міністерства освіти та науки України, Міністерства внутрішніх справ України, Міністерства цифрової трансформації України, Центру протидії дезінформації Ради національної безпеки і оборони України, Національної академії наук України тощо. Окрім того, необхідно виокремити генеральний напрямок побудови контртерористичного наративу, котрий полягатиме у встановленні напряму інформаційного втручання, пошуку груп, лояльних до потрібного нам вектору, які самостійно формували б високоякісні продукти впливу, координації та управління ними.

Висновки. Таким чином, у результаті проведеного дослідження визначено, що у сучасних умовах роль органів та підрозділів МВС України є досить високою, задля забезпечення захисту національної державності. Важливе завдання української держави на сучасному етапі розвитку, відповідно, вбачається в тому, щоб створити необхідні правові й організаційні умови, сприятливу політичну та соціальну атмосферу для благополуччя населення.

Гарантування соціальної безпеки $\epsilon$ важливим завданням політики забезпечення стабільного та збалансованого розвитку держави як соціальноекономічної системи в Україні через умови становлення соціально орієнтованої економіки. Актуальна проблема ефективного державного регулювання соціальної безпеки потребує вдосконалення підходів до формування методології іï дослідження. Отже, у парадигмі сучасної геополітичної ситуації в Україні та світі, під впливом наростання загроз, зокрема гібридного характеру, безпеці України та загалом унаслідок наростання чинників, загрозливих для безпеки як феномену буття окремої держави й на міжнародному рівні гостро актуалізується питання планомірної та цілеспрямованої освітньо-регуляторної політики щодо превентивних заходів із мінімізації загроз національній та індивідуальній безпеці громадянина.

Перспективним напрямом подальших досліджень 3 цієї проблематики $є$ оцінка ефективності забезпечення благополуччя населення, що представляє, як наукову, так і прикладну цінність та розробка оптимальної методики, що дозволить у короткий термін та 3 мінімальними витратами запровадити елементи національної безпеки на відповідній території країни.

\section{Jimepamypa:}

1. Ситник Г. П. Державне управління у сфері національної безпеки (концептуальні та організаційно-правові засади): Підручник. Київ: НАДУ, 2011. 730 с.

2. Про національну безпеку України : Закон України від 21.06.2018 № 2469-VIII, редакція станом на 24.10.2020 // Відомості Верховної Ради України. URL: https://zakon.rada.gov.ua/laws/show/2469-19\#Text (дата звернення 13.01.2022). 
3. Конституція України : Закон України від 28.06.1996 № 254к/96-ВР, редакція станом на 01.01.2020 // Відомості Верховної Ради України. URL: https://zakon.rada.gov.ua/laws/ show/254\%D0\%BA/96-\%D0\%B2\%D1\%80\#Text (дата звернення 13.01.2022).

4. Федорова А. М. Нормативно-правове регулювання питань забезпечення безпечного середовища життя громадян. Публічне управління та регіональний розвиток. 2019. №3. С.162-177.

5. Ilyash $\mathrm{O}$. The principles of state regulation in the sphere of socioeconomic security of Ukraine. Економічний часопис, 2014, XXI 07-08(1):24-28. URL: https://www.ceeol.com/search/ article-detail?id=198323 (дата звернення 13.01.2022).

6. Ілляшенко О. В., Шкарупета О. О. Соціальна система як об’єкт безпеки. Економічна стратегія і перспективи розвитку сфери торгівлі та послуг. 2018. Вип. 1. С. 233-246. URL: http://nbuv.gov.ua/UJRN/esprstp_2018_1_24 (дата звернення 13.01.2022).

7. Большая Советская Энциклопедия. Т. 1, Ст. 47. Изд. 2-е. М. : Политиздат, 1979. 108 с.

8. Гутман Г. В. Управление региональной экономикой / Г. В. Гутман, А. А. Мироедов, С. В. Федин ; под ред. Г. В. Гутмана. М. : Финансы и статистика, 2001. 176 с.

9. Лексин И. Территориальное устройство государства: попытка реализации системной методологии анализа. Рос. экон. журнал. 2003. № 1. С. 55-74.

10. Основи стійкого розвитку : навч. посіб. / [О. І. Карінцева, С. М. Шевченко, М. К. Шапочка та ін.] ; за заг. ред. Л. Г. Мельника. Суми : Університетська книга, 2005. 654 с.

11. Про рішення Ради національної безпеки і оборони України від 15 жовтня 2021 року "Про Стратегію інформаційної безпеки: Указ Президента України №685/2021 // Відомості Верховної Ради України. URL: https://www.president.gov.ua/documents/6852021-41069 (дата звернення 13.01.2022).

12. Про основні засади забезпечення кібербезпеки України: Закон України від 05.10.2017 № 2163-VIII // Відомості Верховної Ради України. URL: https://kodeksy.com.ua/ pro_osnovni_zasadi_zabezpechennya_kiberbezpeki_ukrayini.htm (дата звернення 13.01.2022).

\section{References:}

1. Sytnyk, H. P. (2011). Derzhavne upravlinnia u sferi natsionalnoi bezpeky (kontseptualni ta orhanizatsiino-pravovi zasady). [Public administration in the field of national security (conceptual and organizational and legal principles)]: Pidruchnyk. Kyiv: NADU. 730 p. [in Ukrainian].

2. Pro natsionalnu bezpeku Ukrainy : Zakon Ukrainy vid 21.06.2018 № 2469-VIII, redaktsiia stanom na 24.10.2020 // Vidomosti Verkhovnoi Rady Ukrainy. (2018). Available at: https://zakon.rada.gov.ua/laws/show/2469-19\#Text [in Ukrainian].

3. Konstytutsiia Ukrainy: Zakon Ukrainy vid 28.06.1996 № 254k/96-VR, redaktsiia stanom na 01.01.2020 // Vidomosti Verkhovnoi Rady Ukrainy. (1996). Available at: https://zakon.rada.gov.ua/laws/show/254\%D0\%BA/96-\%D0\%B2\%D1\%80\#Text [in Ukrainian].

4. Fedorova, A. M. (2019). Normatyvno-pravove rehuliuvannia pytan zabezpechennia bezpechnoho seredovyshcha zhyttia hromadian. [Regulatory regulation of a safe living environment for citizens]. Publichne upravlinnia ta rehionalnyi rozvytok. №3. pp.162-177. [in Ukrainian].

5. Ilyash, O. (2014). The principles of state regulation in the sphere of socioeconomic security of Ukraine. Economic Journal, XXI 07-08(1):24-28. Available at: https://www.ceeol.com/ search/article-detail?id=198323 [in English].

6. Illiashenko, O. V., Shkarupeta, O. O. (2018). Sotsialna systema yak obiekt bezpeky. [Social system as an object of security]. Ekonomichna stratehiia i perspektyvy rozvytku sfery torhivli ta posluh. Vyp. 1. pp. 233-246. Available at: http://nbuv.gov.ua/UJRN/esprstp_2018_1_24 [in Ukrainian].

7. Bolshaya Sovetskaya Entsiklopediya. (1979). [The Great Soviet Encyclopedia]. T. 1, St. 47. Izd. 2-e. M. : Politizdat. 108 p. [in Russian].

8. Gutman, G. V. (2001). Upravlenie regionalnoy ekonomikoy. [Management of the regional economy] / G. V. Gutman, A. A. Miroedov, S. V. Fedin ; pod red. G. V. Gutmana. M. : Finansyi i statistika. 176 s. [in Russian]. 
9. Leksin, I. (2003). Territorialnoe ustroystvo gosudarstva: popyitka realizatsii sistemnoy metodologii analiza. [Territorial structure of the state: an attempt to implement a systematic methodology of analysis]. Ros. ekon. zhurnal. № 1. pp. 55-74. [in Russian].

10. Osnovy stiikoho rozvytku : navch. posib. (2005). [Fundamentals of sustainable development: textbook. method]. / [O. I. Karintseva, S. M. Shevchenko, M. K. Shapochka ta in.] ; za zah. red. L. H. Melnyka. Sumy : Universytetska knyha. 654 p. [in Ukrainian].

11.Pro rishennia Rady natsionalnoi bezpeky i oborony Ukrainy vid 15 zhovtnia 2021 roku "Pro Stratehiiu informatsiinoi bezpeky: Ukaz Prezydenta Ukrainy №685/2021 // Vidomosti Verkhovnoi Rady Ukrainy. 2021. Available at: https://www.president.gov.ua/documents/6852021-41069 [in Ukrainian].

12.Pro osnovni zasady zabezpechennia kiberbezpeky Ukrainy: Zakon Ukrainy vid 05.10.2017 № 2163-VIII // Vidomosti Verkhovnoi Rady Ukrainy. 2017. Available at: https://kodeksy.com.ua/ pro_osnovni_zasadi_zabezpechennya_kiberbezpeki_ukrayini.htm [in Ukrainian]. 